\title{
Human-elephant interactions in areas surrounding the Rungwa, Kizigo, and Muhesi Game Reserves, central Tanzania
}

\author{
Kwaslema Malle Hariohay, Wilbright Abraham Munuo and Eivin Røskaft
}

\begin{abstract}
This study assesses the patterns of crop damage by elephants Loxodonta africana in areas adjacent to the Rungwa, Kizigo and Muhesi Game Reserves in Tanzania. We used a questionnaire survey to collect data from a total of 210 household heads from seven villages, with 30 household heads in each village, during June-August 2015. Proximity was a significant factor influencing losses, with crop farms within $<_{1} \mathrm{~km}$ from the reserves having higher losses, followed by those $1-5 \mathrm{~km}$ and $>5 \mathrm{~km}$ distant. Most households $(81.0 \%)<1 \mathrm{~km}$ from a reserve reported crop damage whereas those within $1-5 \mathrm{~km}(65.9 \%)$ and $>5 \mathrm{~km}$ (20.0\%) reported less damage. Most of the losses (79.8\%) occurred in the first half of the year (the wet season). Immigrants reported higher average losses to crops than Indigenous respondents. Noise making, flashlights, setting fire around fields and disturbance by shooting were the methods used to deter elephants from entering crop fields. We recommend that communities around these game reserves avoid areas that are $<_{1} \mathrm{~km}$ from the reserve boundary, plant crops such as chilli, use honeybee Apis mellifera fences to deter elephants from their crops, and receive education on available mitigation methods, to help minimize crop losses to elephants.
\end{abstract}

Keywords Crop damage, game reserve, human-elephant interaction, impacts of elephants, Loxodonta africana, mitigation, Tanzania

Supplementary material for this article is available at https://doi.org/10.1017/Soo3060531800128X

Kwaslema Malle HariohaY ${ }^{*}$ Tanzania Wildlife Research Institute, Arusha, Tanzania

Wilbright Aвraham Munuo $\dagger$ and Eivin RøsKaft (Corresponding author, (D) orcid.org/0000-0003-0262-8443) AfricanBioServices, Department of Biology, Norwegian University of Science and Technology, Realfagbygget, No-7491, Trondheim, Norway. Email roskaft@bio.ntnu.no

${ }^{*}$ Also at: AfricanBioServices, Department of Biology, Norwegian University of Science and Technology, Trondheim, Norway

$\dagger$ †lso at: Tanzania Wildlife Management Authority, Morogoro, Tanzania

Received 7 February 2018. Revision requested 16 May 2018.

Accepted 10 October 2018. First published online 14 November 2019.

\section{Introduction}

ncroachment on wildlife habitats as a result of human sults in the fragmentation and loss of elephant habitat (Dublin \& Hoare, 2004; Kikoti et al., 2011; Western et al., 2015; Shaffer et al., 2019). This has brought elephants and humans into close proximity, intensifying interactions between them (Hoare, 2015; Redpath et al., 2015). Tanzania has a large population of African elephants Loxodonta africana (Mduma et al., 2010; Chase et al., 2016) that inhabits c. $45,000 \mathrm{~km}^{2}$ of central Tanzania, where relatively sparse human populations are living in scattered communities, relying predominantly on subsistence farming (Mduma et al., 2010). Within this area the Rungwa, Kizigo and Muhesi Game Reserves support a high concentration of elephants (Mduma et al., 2010; Tanzania Wildlife Research Institute, 2015; Chase et al., 2016). These reserves are unfenced, facilitating elephant movements into the surrounding areas (Ministry of Natural Resources and Tourism, 2011). Crop farmers need access to fertile land and water, but the elephants also use the same areas as corridors for movement, leading to conflicts (Sitienei et al., 2014; Von Gerhardt et al., 2014; Røskaft et al., 2015). Elephants receive conservation attention from various institutions, including wildlife authorities, non-governmental organizations, international organizations and inter-governmental organizations (Røskaft et al., 2015). The species is imbued with a high existence value by people in the developed world, who find elephants alluring because of their power, beauty, size and connection to wild nature (Dickman, 2010). This high existence value has generated considerable market value globally, manifested predominantly through photographic tourism, trophy hunting, and zoos (Dickman, 2010; Dickman \& Hazzah, 2016). Although the international community ascribes a high value to elephants, local human communities may incur substantial costs from living close to them, including economic losses from crop damage. This can be devastating in impoverished rural communities where crop farming is a major livelihood (Graham et al., 2010; Røskaft et al., 2015; Dickman \& Hazzah, 2016). Other direct costs include damage to property such as infrastructure and water systems, attacks on people, and injuries or loss of life.

Coexistence with elephants entails both indirect and opportunity costs (Barua et al., 2013; Khumalo \& Yung, 2015; Blair \& Meredith, 2017). The economic cost can be 
substantial for people who invest in crop farming, guarding and elephant control systems. The time required for farm protection limits the amount of time available for activities such as attending school, and families who are affected severely by crop damage are unable to pay expenses such as school fees (Alcamo et al., 2003; Khumalo \& Yung, 2015; Røskaft et al., 2015). Additionally, people feel unsafe during daily activities such as walking to and from school, collecting firewood and accessing shops (Dickman \& Hazzah, 2016; Mayberry et al., 2017). This may affect the socio-economic development of communities (Alcamo et al., 2003; Graham et al., 2010; Barua et al., 2013; Chapman et al., 2015; Røskaft et al., 2015; Fisher, 2016).

In human-modified landscapes, animals with large home ranges, such as the African and Asian Elephas maximus elephants, may enter fields, causing crop damage either by foraging on crops or trampling (Gubbi, 2012; Blair \& Meredith, 2017; Shaffer et al., 2019). Human-elephant interaction is a major challenge facing the management of protected areas in both Africa and Asia (Sarker, 2010; Gubbi, 2012; Mace et al., 2018). The negative impacts of elephants are associated with increasing settlement and farming activities close to protected areas. This increases the likelihood of contact with elephants when they leave the protected area (Shaffer et al., 2019). Elephants tend to move outside protected areas when crops are ripening, attracted by crop sugar content and palatability (Stearns \& Stearns, 2010; Gubbi, 2012; Blair \& Meredith, 2017). Frequent crop damage causes farmers to develop negative attitudes towards the conservation of elephants and to be disinclined to share land with them (Hoare, 2015; Hariohay et al., 2018).

Mitigating the impacts of elephants is hindered by poor living standards in developing countries, where people may still clear new fields by cutting trees in areas of former elephant habitat (Dublin \& Hoare, 2004; Gubbi, 2012; Hariohay et al., 2019; Shaffer et al., 2019). Increased human population density results in increased contact between elephants and people, especially in areas adjacent to protected areas (Khumalo \& Yung, 2015; Acharya et al., 2016). The Tanzanian government has introduced a compensation scheme for people affected by problem animals such as elephants, based on the distance people live from a protected area (United Republic of Tanzania, 2011). The scheme covers crop losses and property damage, depredation of livestock, and injuries and fatalities to people (United Republic of Tanzania, 2009, 2011). Compensation for crop losses is per ha up to a maximum of 5 ha, with no compensation for farms within $0.5 \mathrm{~km}$ of a protected area. Compensation for crop farms $0.5^{-1} \mathrm{~km}, 1-4 \mathrm{~km}$, $4-5 \mathrm{~km}$ and $>5 \mathrm{~km}$ from a protected area is USD 11, 22, 33 and 44 per acre ( $0.41 \mathrm{ha}$ ), respectively (United Republic of Tanzania, 2011). At the time of the establishment of this project we used these distances, set by the Government (United Republic of Tanzania, 2009), but we were not able to find any evidence of the use of these criteria, and the compensation scheme is not well known. The Wildlife Conservation Act of 2009 (United Republic of Tanzania, 2009, 2011, 2018) discourages human activities within $0.5 \mathrm{~km}$ of protected areas, but there has not been any research on how the Act affects settlement close to protected areas.

There is increasing pressure on protected areas from surrounding communities as a result of expansion of crop farming fuelled by an annual human population growth rate in Tanzania of c. 3.0\% (United Republic of Tanzania, 2017). Farming is encroaching on elephant habitats, and there is a need to document and analyse the pattern of impacts of elephants on crop farms. Improved knowledge of the pattern and frequency of impacts based on distance from protected area boundaries will enable wildlife managers to educate farmers regarding safe distances from reserve boundaries for farming (Blair \& Meredith, 2017; Shaffer et al., 2019). Acharya et al. (2016) recommended avoiding areas nearest to reserve boundaries in Nepal. Gubbi (2012) and Hill (1997) found greater damage to farms closest to reserve boundaries in southern India and western Uganda, respectively. However, the relationship between distance from a protected area and the types of crop damage by African elephants requires further investigation. Apart from avoiding areas close to protected areas, other mitigation measures used to prevent elephants damaging crops include planting unpalatable crops such as chilli around farms, and beehive fences (Enukwa, 2017).

The challenge of managing co-existence between elephants and people arises because different people have different views or interests, and also because elephants are viewed as dangerous and destructive animals (Dublin \& Hoare, 2004; Blair \& Meredith, 2017). Research on humanelephant interactions can therefore improve knowledge of the costs associated with land-sharing between people and elephants (Graham et al., 2010; Barua et al., 2013). Understanding the dynamics of these interactions can help identify management strategies to protect both humans and elephants. Traditional mitigation measures, such as chasing elephants away by shouting, drum-beating, noise-making, use of fire crackers, or using lights and torches, are diverse yet often ineffective because they address the symptoms of the problem rather than its causes (Graham et al., 2010; Hoare, 2015). Sustainable solutions that reduce or minimize elephant impacts require that spatial and temporal patterns of elephant movement are incorporated into land-use planning and, in addition, that the needs of local communities are recognized in mitigation schemes.

The main objective of this study was to assess the spatiotemporal impacts of elephants on crop farms in areas adjacent to the Rungwa, Kizigo and Muhesi Game Reserves, Tanzania. We tested three hypotheses: (1) elephant impacts are higher on farms $<_{1} \mathrm{~km}$ from protected area boundaries than on farms located $1-5 \mathrm{~km}$ or $>_{5} \mathrm{~km}$ from the 


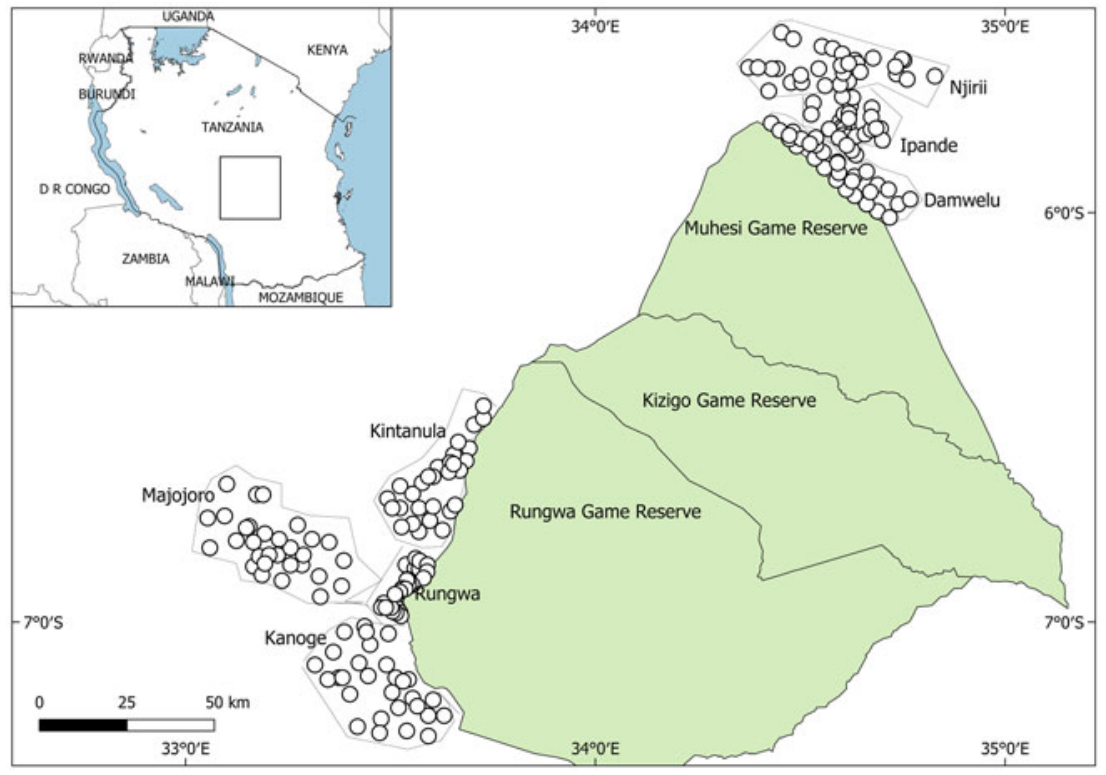

FIG. 1 Locations of the 210 households (circles) in the seven villages (3o households in each) in which we conducted the questionnaire survey. boundaries (because crops are more accessible close to the boundary); (2) there will be a higher frequency of crop damage incidents in the wet than in the dry season because the wet season (January-June) is when crops are cultivated; (3) immigrant farmers experience more frequent damage to their crops by elephants than do Indigenous farmers because the former tend to establish fields closer to reserve boundaries.

\section{Study area}

Rungwa, Kizigo, and Muhesi Game Reserves, covering a total area of $17,340 \mathrm{~km}^{2}$, lie in the Manyoni District in central Tanzania (Ministry of Natural Resources and Tourism, 2011; Fig. 1). According to the most recent dry season aerial census, in 2015, these reserves have the largest elephant population in Tanzania, with an estimated 15,836 individuals (Tanzania Wildlife Research Institute, 2015; Chase et al., 2016). The reserves are unfenced, with no clearly established buffer zone, and are bordered by a public road to the north. Along this public road, people have established settlements and crop farms. Formerly there were no restrictions on the establishment of human settlements and crop farming outside the reserves but the Tanzania Wildlife Conservation Act no. 5 of 2009 sections 5(b) and 74, and recent regulation on wildlife corridors and dispersal areas (United Republic of Tanzania, 2018), describe the requirement for securing buffer zones, wildlife corridors, dispersal areas, and critical habitats for core protected areas. Settlements and farming are banned in these areas (United Republic of Tanzania, 2009, 2018). The landscape of the study area is characterized by shrublands, open forests, settlements and urbanization. Within these open forests and shrublands people cultivate crops; these areas also provide habitat for elephants (Fig. 1).

\section{Methods}

\section{Sample units and design}

We conducted a questionnaire-based survey in a total of 210 households in seven villages around the three game reserves during June-August 2015. In each village we selected 30 households, and in each household only the head or a representative adult male or female responded to our questionnaire. Here, an adult means any member of the household who was $\geq 18$ years old. As defined by the United Republic of Tanzania (2013) a household 'refers to a person or group of persons who reside in the same homestead/compound but not necessarily in the same dwelling unit, have same cooking arrangements and are answerable to the same household head'. We used stratified random sampling to select the villages for surveying, where the attributes of the strata were villages that used to be corridors for elephants. Elephants used to pass through Kanoge, Majojoro, Rungwa and Kintanula villages to the Rukwa/Lukwati and Ugala Game Reserves. Three other villages (Damwelu, Ipande and Njirii) are in wildlife corridors and dispersal areas for elephants. These corridors connect the Muhesi Game Reserve to Chaya and Wembere Game Controlled Areas (Mduma et al., 2010). In the selected villages we used random sampling to select households. Estimates of the number of households in each village were obtained from village leaders at the time of the survey: Kanoge (320), Majojoro (500), Rungwa (450), Kintanula (250), Damwelu (400), Ipande (500) and Njirii (300). Village leaders created registers of the names of available households, and we randomly sampled from these. The total number of households in the seven villages was 2,720 , and thus we sampled $7.7 \%$ of the total. For each household we 
estimated the distance of its farm to the nearest reserve boundary, which we later grouped into three distance categories: $<_{1} \mathrm{~km}, 1-5 \mathrm{~km}$, and $>5 \mathrm{~km}$ from the game reserve boundary. The Tanzanian government considers a distance of $<0.5 \mathrm{~km}$ from the protected area boundary as a buffer zone and, therefore, there is no compensation of crop loss to animals for farms at this distance (United Republic of Tanzania, 2011).

\section{Questionnaire survey}

The questionnaire survey included both closed and openended questions (Supplementary Material 1). The questions enquired about immigration status (migration from regions other than Singida, Dodoma, Tabora and Mbeya), farm size and distance to the nearest reserve boundary, and incidents and proportion of crop damaged by elephants (and any mitigation measures) during 1 June 2014-31 May 2015. The ethnic groups resident in the study area were Taturu, Nyaturu, Gogo, Kimbu and Nyamwezi; immigrants were recorded as Sukuma and others. Immigrants were people who had moved to the area after so-called operation village (the process of establishment and formal recognition of villages) during 1972-1974. All interviewees gave prior, informed consent before they were included in the survey. At the beginning of the interviews, respondents were informed they could seek clarification at any time during the interview. KMH and WAM conducted the questionnaire survey, in Swahili. We anonymized respondents by not asking their names and assigned a number to each questionnaire.

\section{Data analysis}

We performed all statistical data analyses using SPSS 21.0 (IBM, New York, USA). We examined differences in crop damage incidence (with a $\chi^{2}$ test) and mean area of crop damaged (with an $F$ test to compare two variances) by elephants, partitioned by six independent variables: village, farm distance to nearest game reserve boundary $\left(<_{1} \mathrm{~km}\right.$, $1-5 \mathrm{~km}$ and $>5 \mathrm{~km}$ ), season (wet: January-June; dry: JulyDecember; annual: January-December), immigration status (Indigenous, immigrants), farm size $\left(<11,11-20,>_{20}\right.$ ha), and water sources shared with elephants (yes/no). We also used a generalized linear model to investigate the effect of village, farm distance to nearest game reserve boundary, season, immigration status, farm size, and water sources shared with elephants on the area of crop damaged. Significance level was $\mathrm{P}<0.05$.

\section{Results}

Mean age of respondents was $44.6 \pm$ SD 12.4 years, with $34.3 \%$ of the 210 respondents aged $44-56,29.0 \%>56$ years, $22.9 \% 31-43$, and $13.8 \% 18-30$ years. The majority of respondents $(67.1 \%)$ were male. Ninety households were $>5 \mathrm{~km}$ from the reserves' boundary, 79 were $<_{1} \mathrm{~km}$, and 41 were within $1-5 \mathrm{~km}$. Of the 210 respondents, $52.4 \%$ were immigrants and $47.6 \%$ were Indigenous. Kanoge village had the greatest proportion of immigrant respondents (86.7\%), followed by Damwelu (70.0\%), Majojoro (56.7\%), Kintanula (53.3\%), Ipande (50.0\%), Rungwa (43.3\%) and Njirii (6.7\%). Mean household size was $9.5 \pm$ SD 5.9 people (range 1-56). Immigrants had a greater mean household size (11.6 \pm SD 6.9 individuals) than Indigenous people (7.3 \pm SD 3.3).

When we asked respondents to mention the major problem caused by elephants, $51.9 \%$ mentioned crop damage, followed by damage to infrastructure such as water taps (19.5\%), fear of collecting firewood (17.2\%), and impeded access to shops and schools (11.4\%). The frequencies of reported crop damage incidents varied significantly between villages, with the highest numbers of crop damage incidences recorded in Kanoge, followed by Kintanula, Rungwa, Damwelu, Ipande and Majojoro, and the fewest reports from Njirii (Table 1). Crop damage incidents varied significantly with distance from farm to the nearest reserve boundary (Table 1). Most of the respondents with farms $<_{1} \mathrm{~km}$ from the boundry (81.0\%) reported crop damage by elephants as a major problem, followed by those with arms 1-5 km (65.9\%). Few respondents with farms $>5 \mathrm{~km}$ (20.0\%) reported this as a major problem.

The estimated annual total losses as a result of elephant damage were 437.5 ha of crops, a mean of $4.0 \pm$ SD 4.6 ha per affected household per year. The estimated losses varied with distance to the nearest reserve boundary, with those $<_{1} \mathrm{~km}$ reporting the greatest mean crop losses and those $>5 \mathrm{~km}$ the lowest mean crop losses (Table 2). The villages of Rungwa, Damwelu, Kanoge and Kintanula reported significantly more losses than the villages of Ipande, Njirii and Damwelu. Among the 109 households that incurred crop damage, most respondents (79.8\%) reported the wet season to be the time in which most crop damage by elephants occurred, followed by the dry season (17.4\%); some respondents $(2.8 \%)$ reported damage throughout the year.

Among the 110 immigrant households, $47.3 \%$ had farms close to the nearest reserve boundary, $30.0 \%>5 \mathrm{~km}$, and 22.7\% 1-5 km distant; the majority of the 100 Indigenous respondents (57.0\%) owned farms far from the nearest reserve boundary $(>5 \mathrm{~km})$, followed by $27.0 \%<_{1} \mathrm{~km}$ and $16.0 \% 1-5 \mathrm{~km}$ distant $\left(\chi^{2}=15.84, \mathrm{df}=2, \mathrm{P}<0.001\right.$. Most immigrants $(73.6 \%)$ reported crop damage incidents by elephants as the major problem whereas only a few of the Indigenous people (28.0\%) reported this as a major problem (Table 1). Immigrants were farming larger areas (mean $8.6 \pm$ SD 9.0 ha) than Indigenous people (mean $4.1 \pm$ SD 3.2 ha; $F=22.33, \mathrm{df}=1, \mathrm{P}<0.001$ ). Immigrants experienced greater mean losses of crops to elephants than Indigenous respondents (Table 2). 
TABLE 1 Crop damage reported by 210 respondents, by village, nearest distance to game reserve boundary, season, immigration status, and water sources shared with elephants Loxodonta africana, with Pearson $\chi^{2}$ test for differences within each of the four variables.

\begin{tabular}{|c|c|c|c|c|c|c|c|}
\hline \multirow[b]{2}{*}{ Variable } & \multirow[b]{2}{*}{ Attribute } & \multicolumn{3}{|c|}{ Crop damage (\%) } & \multirow[b]{2}{*}{$\chi^{2}$} & \multirow[b]{2}{*}{$\mathrm{df}$} & \multirow[b]{2}{*}{$\mathrm{P}$} \\
\hline & & Yes & No & $\mathrm{n}$ & & & \\
\hline \multirow[t]{7}{*}{ Village } & Kanoge & 93.3 & 6.7 & 30 & 79.28 & 6 & $<0.001$ \\
\hline & Kintanula & 83.3 & 16.7 & 30 & & & \\
\hline & Rungwa & 60.0 & 40.0 & 30 & & & \\
\hline & Damwelu & 56.7 & 43.3 & 30 & & & \\
\hline & Ipande & 53.3 & 46.7 & 30 & & & \\
\hline & Majojoro & 10.0 & 90.0 & 30 & & & \\
\hline & Njirii & 6.7 & 93.3 & 30 & & & \\
\hline \multirow[t]{3}{*}{ Farm distance to nearest game reserve boundary $(\mathrm{km})$} & $<1 \mathrm{~km}$ & 81.0 & 19.0 & 79 & 53.96 & 2 & $<0.001$ \\
\hline & $1-5 \mathrm{~km}$ & 65.9 & 34.1 & 41 & & & \\
\hline & $>5 \mathrm{~km}$ & 20.0 & 80.0 & 90 & & & \\
\hline \multirow[t]{3}{*}{ Season } & Wet & 61.7 & 38.3 & 141 & 22.79 & 2 & $<0.001$ \\
\hline & Dry & 35.8 & 64.2 & 53 & & & \\
\hline & Both wet \& dry & 18.8 & 81.2 & 16 & & & \\
\hline \multirow[t]{2}{*}{ Immigration status } & Indigenous & 28.0 & 72.0 & 100 & 51.51 & 1 & $<0.001$ \\
\hline & Immigrants & 73.6 & 26.4 & 110 & & & \\
\hline \multirow[t]{2}{*}{ Water sources shared with elephants } & Yes & 75.2 & 24.8 & 158 & 41.15 & 1 & $<0.001$ \\
\hline & No & 24.8 & 75.2 & 52 & & & \\
\hline
\end{tabular}

TABLE 2 Estimated mean area of crops damaged by elephants reported by the 109 households that indicated crop damage was a major problem, by village, nearest distance to reserve boundary, season, immigration status, farm size and water sources shared with elephants, with $F$ test for differences within each of the four variables.

\begin{tabular}{|c|c|c|c|c|c|c|}
\hline Variable & Attribute & Mean \pm SD (ha) & $\mathrm{n}$ & $F$ & df & $\mathrm{P}$ \\
\hline \multirow[t]{7}{*}{ Village } & Damwelu & $7.9 \pm 5.8$ & 17 & 8.60 & 6 & $<0.001$ \\
\hline & Rungwa & $6.2 \pm 4.8$ & 18 & & & \\
\hline & Kanoge & $5.2 \pm 4.1$ & 28 & & & \\
\hline & Kintanula & $1.5 \pm 1.7$ & 25 & & & \\
\hline & Njirii & $1.0 \pm 0.0$ & 2 & & & \\
\hline & Ipande & $0.9 \pm 0.7$ & 16 & & & \\
\hline & Majojoro & $0.8 \pm 0.3$ & 3 & & & \\
\hline \multirow[t]{3}{*}{ Farm distance to nearest game reserve boundary $(\mathrm{km})$} & $<1$ & $5.5 \pm 4.9$ & 64 & 15.64 & 2 & $<0.001$ \\
\hline & $1-5$ & $2.4 \pm 3.6$ & 27 & & & \\
\hline & $>5$ & $0.8 \pm 1.2$ & 18 & & & \\
\hline \multirow[t]{3}{*}{ Season } & Wet & $4.6 \pm 4.8$ & 87 & 4.85 & 2 & 0.010 \\
\hline & Dry & $1.1 \pm 1.9$ & 19 & & & \\
\hline & Both wet \& dry & $0.7 \pm 0.4$ & 3 & & & \\
\hline \multirow[t]{2}{*}{ Immigration status } & Indigenous & $1.8 \pm 2.1$ & 28 & 10.36 & 1 & 0.002 \\
\hline & Immigrants & $4.8 \pm 4.9$ & 81 & & & \\
\hline \multirow[t]{3}{*}{ Farm size (ha) } & $<11$ & $2.5 \pm 2.4$ & 82 & 60.73 & 2 & $<0.001$ \\
\hline & $11-20$ & $10.0 \pm 4.8$ & 22 & & & \\
\hline & $>20$ & $0.8 \pm 0.0$ & 5 & & & \\
\hline \multirow[t]{2}{*}{ Water sources shared with elephants } & Yes & $5.8 \pm 4.4$ & 82 & 5.40 & 1 & 0.022 \\
\hline & No & $3.4 \pm 4.7$ & 27 & & & \\
\hline
\end{tabular}

In the generalized linear model, village, distance to nearest reserve boundary, farm size, shared water sources, presence/absence of elephants, and immigration status together explained $47.3 \%$ of variation in crop damage area, but season did not make a significant contribution (Table 3 ). The majority of respondents (96.2\%) were engaged in multi-crop cultivation of maize, millet, sorghum, tobacco and beans, and $3.8 \%$ cultivated only maize. When asked to describe the crop most damaged by elephants, $56.8 \%$ of farmers mentioned maize only, followed by multiple crops $(19.0 \%$ of farmers), sorghum (9.6\%), beans (8.6\%) and groundnuts (6.0\%). When asked the common reasons for crop damage by elephants, respondents mentioned the field being close to the reserve boundary (30.0\%), elephants searching for water on village land $(20.0 \%)$, the preference of elephants for cultivated crops rather than wild plants (17.1\%), and a 
TABLE 3 Generalized linear model with crop damage area as the dependent variable and six independent variables: village, distance of farm to nearest reserve boundary, season, immigration status, farm size, and water sources shared with elephants.

\begin{tabular}{|c|c|c|c|c|c|c|}
\hline Parameter & Independent variable & B & SE & Wald $\chi^{2}$ & $\mathrm{df}$ & $\mathrm{P}$ \\
\hline \multirow{8}{*}{ Village } & Intercept & 3.79 & 1.59 & 5.66 & 1 & 0.014 \\
\hline & Ipande & -1.82 & 0.35 & 27.33 & 1 & $<0.001$ \\
\hline & Damwelu & 1.44 & 0.31 & 21.86 & 1 & $<0.001$ \\
\hline & Njirii & -1.41 & 0.76 & 3.44 & 1 & 0.064 \\
\hline & Majojoro & -2.50 & 0.81 & 9.65 & 1 & 0.002 \\
\hline & Rungwa & 1.54 & 0.32 & 23.81 & 1 & $<0.001$ \\
\hline & Kintanula & 1.76 & 0.29 & 36.24 & 1 & $<0.001$ \\
\hline & Kanoge & $0^{1}$ & & & & \\
\hline \multirow[t]{3}{*}{ Farm distance to nearest game reserve boundary $(\mathrm{km})$} & $<1$ & 2.73 & 0.44 & 34.84 & 1 & $<0.001$ \\
\hline & $1-5$ & 2.55 & 0.42 & 33.77 & 1 & $<0.001$ \\
\hline & $>5$ & 1.97 & 0.41 & 22.97 & 1 & $<0.001$ \\
\hline \multirow[t]{3}{*}{ Season } & Wet & 0.24 & 0.65 & 0.14 & 1 & 0.709 \\
\hline & Dry & -0.54 & 0.69 & 0.59 & 1 & 0.440 \\
\hline & Both wet \& dry & $0^{1}$ & & & & \\
\hline \multirow[t]{2}{*}{ Immigration status } & Immigrant & 1.97 & 0.41 & 22.97 & 1 & $<0.001$ \\
\hline & Indigenous & $0^{1}$ & & & & \\
\hline \multirow[t]{3}{*}{ Farm size (ha) } & $<11$ & -0.53 & 1.30 & 0.16 & 1 & 0.885 \\
\hline & $11-20$ & 5.50 & 1.32 & 17.38 & 1 & $<0.001$ \\
\hline & $>20$ & $0^{1}$ & & & & \\
\hline \multirow[t]{2}{*}{ Water sources shared with elephants } & Yes & -2.64 & 0.49 & 29.44 & 1 & $<0.001$ \\
\hline & No & $0^{1}$ & & & & \\
\hline
\end{tabular}

${ }^{1}$ This parameter is set to zero because it is redundant.

combination of reasons $(15.3 \%) ; 17.6 \%$ indicated they did not know why elephants damage crops.

Most of the 210 respondents $(148,70.5 \%)$ were aware of mitigation measures, with significantly more Indigenous respondents $(58.8 \%)$ aware of these measures than immigrants (41.2\%; $\left.\chi^{2}=33.28, \mathrm{df}=1, \mathrm{P}<0.001\right)$. Most of the respondents using mitigation $(62.2 \%$ of 148$)$ used a combination of noise making, lighting fires during the night, and launching stones with hand catapults. Other methods included employing someone to guard the fields ( $16.9 \%$ of 148 ), planting unfavourable crops such as chilli around the farm (10.8\%), seeking help from wildlife rangers, who used disturbance shooting (4.7\%), placing hives of honeybees Apis mellifera around crop fields (3.4\%), and placing oil-smeared cloths attached to ropes around crop fields $(2.0 \%)$. Those who employed a combination of methods suffered less mean damage (3.30 \pm SD 3.84 ha), followed by those who planted chilli around the farm (3.35 \pm SD $4.44 \mathrm{ha}$ ), used beehives (4.75 \pm SD $2.62 \mathrm{ha}$ ), employed guards $(5.37 \pm \mathrm{SD} 6.13 \mathrm{ha})$, used oil-smeared cloths on ropes $(6.80 \pm \mathrm{SD} 2.28 \mathrm{ha})$ or used disturbance shooting (9.33 $\pm \mathrm{SD}$ 7.08 ha; $F=2.83, \mathrm{df}=5, \mathrm{P}<0.020)$.

\section{Discussion}

\section{Distance to reserve boundary}

Mean crop damage losses and the frequency with which crop damage by elephants was reported were greatest $<_{1} \mathrm{~km}$ from the Rungwa, Kizigo and Muhesi Game Reserves.
Other studies have also shown that farms close to protected areas experience more crop damage compared to those further away (Nahonyo, 2005; Okello et al., 2008; Sarker, 2010; Blair \& Meredith, 2017). However, estimates of crop losses caused by elephants can be exaggerated by affected communities (Enukwa, 2017; Shaffer et al., 2019). In our study, we diminished this possibility by elaborating the questions to the respondent before we recorded answers. This ensured that respondents understood the questions and provided correct answers, by giving them time to crosscheck their answers. Not all farms close to reserves experience crop losses to elephants, and the frequency of crop losses often varies: not all farms closest to reserve boundaries are damaged (Graham et al., 2010; Von Gerhardt et al., 2014). Similarly, we found that c. $22 \%$ of farmers who had farms $<_{1} \mathrm{~km}$ from a reserve boundary did not experience crop damage by elephants.

Crop damage is only a part of the Tanzania consolation scheme regulation (United Republic of Tanzania, 2011). Crop loss to elephants is not fully compensated, and compensation varies with distance from protected areas; losses to farms within $0.5 \mathrm{~km}$ do not receive any compensation. Our findings support our first hypothesis that crop damage incidents increase with decreasing distance of farms to a game reserve boundary.

\section{Season}

Respondents indicated that crop damage by elephants was higher during the wet season. Although in the generalized 
linear model season did not make a significant contribution to the area of crop damaged, this result could have been influenced by interactions of other variables in the model, as the univariate analysis indicated greater average losses of crops in the wet season. Rainfall determines the growth of the farm-bush mosaic, which is attractive to elephants, and rainfall promotes growth of crops, such as maize, which when mature attract elephants (Barnes et al., 2007; Gubbi, 2012). During the dry season there was a lower frequency of crop damage, as we hypothesized, because during these months there is less crop cultivation. However, during the dry season a few crops, such as vegetables and tobacco seedlings, are grown near rivers in the study area. In this season elephants will move outside the reserves to search for water and may cause damage to vegetables grown along the river and at water points (Barnes \& Dunn, 2002; Sitati et al., 2005; Barnes et al., 2007; Sitienei et al., 2014).

\section{Immigration status}

Our findings indicated that Indigenous respondents were more aware than immigrants of mitigation measures. As envisaged in our third hypothesis, more immigrants than Indigenous respondents experienced crop damage by elephants, mainly because of differences in farming practices, with most immigrants farming near the borders of the game reserves, similar to the findings of research elsewhere (Lyamuya et al., 2014; Acharya et al., 2016). Indigenous people whose families have resided in the area for several generations are more likely to be aware of local geography, seasonality and elephant dynamics. In our study immigrants, who are from agro-pastoralist groups, cultivated larger farms than Indigenous people, possibly because they had larger households and consequently greater food requirements (Redpath et al., 2015; Acharya et al., 2016).

\section{Types of crops damaged and mitigation methods}

Most of the respondents in our study area listed maize as the crop most vulnerable to elephants, probably because maize is the main food crop in this area. During the maturing stage, in the wet season, maize attracts elephants because of its high sugar content (Barnes \& Dunn, 2002; Gubbi, 2012). Measures applied by the farmers in our study to deter elephants included simple, affordable methods such as noise making, use of flashlights, setting fire around the fields, and firing stones from hand catapults. Noise making involves hitting tins and drums, yelling, and sometimes whistling, to deter elephants away from the fields (Osborn \& Parker, 2003; Khumalo \& Yung, 2015). The farmers also noted that the wildlife authorities used disturbance shooting to deter elephants from fields, but rarely destroyed problem elephants. Disturbance shooting, and the destruction of problem elephants have been used by wildlife authorities near protected areas in Kenya to deter elephants from fields (Dublin \& Hoare, 2004; Hoare, 2015). Respondents in our study area also used chilli to help deter elephants. Compared to crops such as maize and sorghum, chilli is less palatable to elephants and is a cash crop with high economic value (Parker \& Osborn, 2006; Khumalo \& Yung, 2015). Our respondents also reported the use of beehives. Noise from honeybees is a deterrent to elephants, which upon hearing the sound from disturbed honeybees produce alarm calls that cause members in the group to move away from the source of the sound (King et al., 2010). The use of beehive fences, although effective, is potentially limited by lack of funds.

\section{Conclusion}

Farmers cultivating crops $<_{1} \mathrm{~km}$ from the nearest boundary of the Rungwa, Kizigo and Muhesi Game Reserves experienced more crop damage by elephants compared to those with farms further away, damage was higher in the wet season when palatable crops are mature, and immigrants to the area, who tend to farm closer to the reserves, suffered greater crop damage by elephants than did Indigenous respondents. Based on our findings, we make four recommendations. Firstly, farmers should be discouraged from planting crops $<_{1} \mathrm{~km}$ from a reserve boundary, in combination with the establishment of a $1 \mathrm{~km}$ buffer zone within which only activities such as beekeeping and tree planting are allowed. Secondly, we recommend the use of a combination of mitigation methods, including increased planting of crops that are less palatable to elephants, such as chilli, and the use of honeybee fences around farms. Thirdly, we recommend increasing the amount of compensation available to farmers when they lose crops to elephants, rather than the current situation in which affected farmers are compensated for only a small proportion of the total loss. Fourthly, we recommend education on available mitigation methods, to help farmers living in areas adjacent to the game reserves minimize crop losses to elephants.

Acknowledgements We thank the Norwegian government and the EU Horizon-2020 financed project under GA 641918 (to AfricanBioServices) for funding the compilation of this research, the Tanzania Wildlife Management Authority and the Tanzania Wildlife Research Institute for granting us access to conduct this research, Patrice Richard for his help in the field, and two anonymous reviewers for helpful comments.

Author contributions Study design: WAM, KMH, ER; data collection and analysis: WAM; writing: KMH, ER, WAM.

\section{Conflicts of interest None.}


Ethical standards This research abided by the Oryx guidelines on ethical standards. A permit to conduct research was obtained from the relevant wildlife authority prior to field work.

\section{References}

Acharya, K.P., Paudel, P.K., Neupane, P.R. \& Köhl, M. (2016) Human-wildlife conflicts in Nepal: patterns of human fatalities and injuries caused by large mammals. PLOS ONE, 11, e0161717.

Alcamo, J., Bennett, E. \& Assessment, M.E. (2003) Ecosystems and Human Well-Being: a Framework for Assessment. Island Press, Washington, DC, USA.

BARNES, R.F.W. \& DUnN, A. (2002) Estimating forest elephant density in Sapo National Park (Liberia) with a rainfall model. African Journal of Ecology, 40, 159-163.

Barnes, R.F.W., Dubiure, U.F., Danquah, E., Boafo, Y., Nandjui, A., Hema, E.M. \& Manford, M. (2007) Crop-raiding elephants and the moon. African Journal of Ecology, 45, 112-115.

Barua, M., Bhagwat, S.A. \& Jadhav, S. (2013) The hidden dimensions of human-wildlife conflict: health impacts, opportunity and transaction costs. Biological Conservation, 157, 309-316.

Blair, A. \& Meredith, T. (2017) Community perception of the real impacts of human-wildlife conflict in Laikipia, Kenya: capturing the relative significance of high-frequency, low-severity events. Oryx, 52, 497-507.

Chapman, C.A., Van Bavel, B., Boodman, C., Ghai, R.R., Gogarten, J.F., Hartter, J. et al. (2015) Providing health care to improve community perceptions of protected areas. Oryx, 49, 636-642.

Chase, M.J., Schlossberg, S., Griffin, C.R., Bouché, P.J.C., Djene, S.W., ElKan, P.W. et al. (2016) Continent-wide survey reveals massive decline in African savannah elephants. PeerJ, 4, e2354.

Dickman, A.J. (2010) Complexities of conflict: the importance of considering social factors for effectively resolving human-wildlife conflict. Animal Conservation, 13, 458-466.

Dickman, A.J. \& HazZAH, L. (2016) Money, myths and man-eaters: complexities of human-wildlife conflict. In Problematic Wildlife-a Cross-Disciplinary Approach (ed. F.M. Angelici), pp. 339-356. Springer, New York, USA.

Dublin, H.T. \& Hoare, R.E. (2004) Searching for solutions: the evolution of an integrated approach to understanding and mitigating human-elephant conflict in Africa. Human Dimensions of Wildlife, 9, 271-278.

ENUKWA, E.H. (2017) Human-elephant conflict mitigation methods: a review of effectiveness and sustainability. Journal of Wildlife and Biodiversity, 1, 69-78.

Fisher, M. (2016) Whose conflict is it anyway? Mobilizing research to save lives. Oryx, 50, 377-378.

Graham, M.D., Notter, B.M., Adams, W.M., Lee, P.C. \& Ochieng, T.N. (2010) Patterns of crop-raiding by elephants, Loxodonta africana, in Laikipia, Kenya, and the management of humanelephant conflict. Systematics and Biodiversity, 8, 435-445.

GubBi, S. (2012) Patterns and correlates of human-elephant conflict around a south Indian reserve. Biological Conservation, 148, 88-95.

Hariohay, K.M., Fyumagwa, R.D., Kideghesho, J.R. \& Røskaft, E. (2018) Awareness and attitudes of local people toward wildlife conservation in the Rungwa Game Reserve in Central Tanzania. Human Dimensions of Wildlife, 23, 503-514.

Hariohay, K.M., Ranke, P.S., Fyumagwa, R.D., Kideghesho, J.R. \& Røsкағт, E. (2019) Drivers of conservation crimes in the Rungwa-Kizigo-Muhesi Game Reserves, Central Tanzania. Global Ecology and Conservation, 17, e00522.
Hill, C.M. (1997) Crop-raiding by wild vertebrates: the farmer's perspective in an agricultural community in western Uganda. International Journal of Pest Management, 43, 77-84.

HoAre, R. (2015) Lessons from 20 years of human-elephant conflict mitigation in Africa: perspective on human-wildlife conflict. Human Dimensions of Wildlife, 20, 289-295.

Khumalo, K.E. \& YunG, L.A. (2015) Women, human-wildlife conflict, and CBNRM: hidden impacts and vulnerabilities in Kwandu Conservancy, Namibia. Conservation and Society, 13, 232-243.

Kikoti, A.P., Griffin, C.R. \& Pamphil, L. (2011) Elephant use and conflict leads to Tanzania's first wildlife conservation corridor. Pachyderm, 48, 57-66.

King, L.E., Soltis, J., Douglas-Hamilton, I., Savage, A. \& Vollrath, F. (2010) Bee threat elicits alarm call in African elephants. PLOS ONE, 5, e10346.

Lyamuya, R.D., Masenga, E.H., Mbise, F., Fyumagwa, R.D., Mwita, M. \& RøsKaft, E. (2014) Human-carnivore conflict over livestock in the eastern part of the Serengeti ecosystem, with a particular focus on the African wild dog Lycaon pictus. Oryx, 48, 378-384.

Mace, G.M., Barrett, M., Burgess, N.D., Cornell, S.E., Freeman, R., Grooten, M. \& Purvis, A. (2018) Aiming higher to bend the curve of biodiversity loss. Nature Sustainability, 1, 448-451.

Mayberry, A.L., Hovorka, A.J. \& Evans, K.E. (2017) Well-being impacts of human-elephant conflict in Khumaga, Botswana: exploring visible and hidden dimensions. Conservation and Society, $15,280-291$.

Mduma, S.R., Lobora, A.L., Foley, C. \& Jones, T. (2010) Tanzania Elephant Management Plan 2010-2015. Tanzania Wildlife Research Institute: Conservation Information and Monitoring Unit, Arusha, Tanzania.

Ministry of Natural Resources and Tourism (2011) RungwaKizigo-Muhesi Game Reserves General Management Plan. Government Printers, Dar es Salaam, Tanzania.

Nahonyo, C.L. (2005) Assessment of anti-poaching effort in Ruaha National Park, Tanzania. Tanzania Journal of Science, 31, 13-22.

Oкello, M.M., Manka, S.G. \& D'amour, D.E. (2008) The relative importance of large mammal species for tourism in Amboseli National Park, Kenya. Tourism Management, 29, 751-76o.

Osborn, F.V. \& PARKer, G.E. (2003) Towards an integrated approach for reducing the conflict between elephants and people: a review of current research. Oryx, 37, 80-84.

Parker, G.E. \& Osborn, F.V. (2006) Investigating the potential for chilli Capsicum spp. to reduce human-wildlife conflict in Zimbabwe. Oryx, 40, 343-346.

Redpath, S., Bhatia, S. \& Young, J. (2015) Tilting at wildlife: reconsidering human-wildlife conflict. Oryx, 49, 222-225.

Røskaft, E., Larsen, T., Mojaphoko, R., Sarker, A.H.M.R. \& JACKSON, C. (2015) Human dimensions of elephant ecology. In Elephants and Savanna Woodland Ecosystems: a Study From Chobe National Park, Botswana, Vol. 14 (eds C. Skarpe, J.T. Du Toit \& S.R. Moe), pp. 271-288. Wiley Blackwell, Oxford, UK.

SARKER, A.H.M.R. (2010) Human-wildlife conflict: a comparison between Asia and Africa with special reference to elephants. In Conservation of Natural Resources: Some African \& Asian Examples (eds E. Gereta \& E. Røskaft), pp. 186-210. Tapir Academic Press, Trondheim, Norway.

Shaffer, L.J., Khadka, K.K., Van den Hoek, J. \& Naithani, K.J. (2019) Human-elephant conflict: a review of current management strategies and future directions. Frontiers in Ecology and Evolution, $6,235$.

Sitati, N.W., Walpole, M.J. \& Leader-Williams, N. (2005) Factors affecting susceptibility of farms to crop raiding by African 
elephants: using a predictive model to mitigate conflict. Journal of Applied Ecology, 42, 1175-1182.

Sitienei, A.J., Jiwen, G. \& Ngene, S.M. (2014) Assessing the cost of living with elephants (Loxodonta africana) in areas adjacent to Meru National Park, Kenya. European Journal of Wildlife Research, 6o, 323-330.

Stearns, B.P. \& Stearns, S.C. (2010) Still watching, from the edge of extinction. BioScience, 6o, 141-146.

Tanzania Wildlife Research Institute (2015) Aerial Census of Large Animals in the Ruaha-Rungwa Ecosystem, Dry Season, Population Status of African Elephant. Government of Tanzania, Ausha, Tanzania.

United Republic of Tanzania (2009) Wildlife Conservation Act No 5 of 2009. Government Printers, Dar es Salaam, Tanzania.

United Republic of Tanzania (2011) The Wildife Conservation (Dangerous Animals Damage Consolation) Regulations. Government of Tanzania, Dar es Salaam, Tanzania.
United Republic of Tanzania (2013) Population and Housing Census: Population Distribution by Administrative Areas.

Government Printers, Dar es Salaam, Tanzania.

United Republic of Tanzania (2017) Tanzania Total Population by District-Regions 2016-2017: Sub-Divisional Population Projection for Year 2016, 2017 Based on 2012 Population and Housing Census. Government printers, Dar es Salaam, Tanzania.

United Republic of Tanzania (2018) The Wildife Conservation (Wildlife Corridors, Dispersal Areas, Buffer Zones and Migratory Routes) Regulations, 2018. Government Printers, Dar es Salaam, Tanzania.

Von Gerhardt, K., Van Niekerk, A., Kidd, M., Samways, M. \& HANKS, J. (2014) The role of elephant Loxodonta africana pathways as a spatial variable in crop-raiding location. Oryx, 48, 436-444.

Western, D., Waithaka, J. \& Kamanga, J. (2015) Finding space for wildlife beyond National Parks and reducing conflicts through community-based conservation: the Kenya experience. Parks, $21,52-62$. 